\title{
Predictive accuracy of computer-aided versions of the on-admission National Early Warning Score in estimating the risk of COVID-19 for unplanned admission to hospital: a retrospective development and validation study
}

\author{
Authors \\ Muhammad Faisal, PhD \\ Senior Research Fellow in Biostatistics \\ Faculty of Health Studies, University of Bradford, Bradford, UK \\ Bradford Institute for Health Research Bradford, UK \\ NIHR Yorkshire and Humber Patient Safety Translational Research Centre (YHPSTRC), Bradford, UK \\ Wolfson Centre for Applied Health Research, Bradford, UK \\ E-mail: M.Faisal1@bradford.ac.uk \\ Mohammed A Mohammed, PhD \\ Professor of Healthcare Quality \& Effectiveness \\ Faculty of Health Studies, University of Bradford, Bradford, UK \\ NHS Midlands and Lancashire Commissioning Support Unit, \\ The Strategy Unit, \\ Kingston House, \\ West Bromwich, B70 9LD, UK \\ E-mail: M.A.Mohammed5@Bradford.ac.uk \\ Donald Richardson, FRCP \\ Deputy Medical Director, Chief Clinical Information Officer, Consultant Renal Physician \\ Department of Renal Medicine, York Teaching Hospitals NHS Foundation Trust \\ E-mail: drichardson@doctors.org.uk \\ Ewout W. Steyerberg, PhD \\ Professor of Medical Decision Making, \\ Department of Public Health, Erasmus University, Rotterdam, The Netherlands \\ Leiden University Medical Center Leiden, The Netherlands \\ E-mail: E.Steverberg@ErasmusMC.nl \\ Massimo Fiori \\ Senior Analyst/ Programmer \\ York Teaching Hospitals NHS Foundation Trust, England UK \\ E-mail: massimo.fiori@york.nhs.uk \\ Kevin Beatson, MSc \\ Head of Systems Development \\ York Teaching Hospitals NHS Foundation Trust, England UK \\ E-mail: Kevin.Beatson@York.NHS.uk
}

Correspondence to: M A Mohammed 


\section{Abstract}

Objectives: To consider the potential of the National Early Warning Score (NEWS2) for COVID-19 risk prediction on unplanned admission to hospital.

Design: Logistic regression model development and validation study using a cohort of unplanned emergency medical admission to hospital.

Setting: York Hospital (YH) as model development dataset and Scarborough Hospital (SH) as model validation dataset.

Participants: Unplanned adult medical admissions discharged over 3 months (11 March 2020 to 13 June 2020 ) from two hospitals (YH for model development; SH for external model validation) based on admission NEWS2 electronically recorded within \pm 24 hours of admission. We used logistic regression modelling to predict the risk of COVID-19 using NEWS2 (Model MO') versus enhanced cNEWS models which included age + sex (model M1') + subcomponents (including diastolic blood pressure + oxygen flow rate + oxygen scale) of NEWS2 (model M2'). The ICD-10 code 'U071' was used to identify COVID-19 admissions. Model performance was evaluated according to discrimination (c statistic), calibration (graphically), and clinical usefulness at NEWS2 $\geq 5$.

Results The prevalence of COVID-19 was higher in SH $(11.0 \%=277 / 2520)$ than $\mathrm{YH}(8.7 \%=343 / 3924)$ with higher index NEWS2 ( 3.2 vs 2.8 ) but similar in-hospital mortality ( $8.4 \%$ vs $8.2 \%$ ). The c-statistics for predicting COVID-19 for cNEWS models (M1',M2') was substantially better than NEWS2 alone (MO') in development ( $\mathrm{M2}^{\prime}: 0.78(95 \% \mathrm{Cl} 0.75-0.80)$ vs $\left.\mathrm{MO}^{\prime} 0.71(95 \% \mathrm{Cl} 0.68-0.74)\right)$ and validation datasets ( $M 2^{\prime}$ : $0.72(95 \% \mathrm{Cl} 0.69-0.75)$ vs $\mathrm{MO}^{\prime} 0.65$ (95\% $\left.\mathrm{Cl} 0.61-0.68\right)$ ). Model $\mathrm{M}^{\prime}$ had better calibration than Model Mo' with improved sensitivity (M2': $57 \%$ (95\% $\mathrm{Cl} 51 \%-63 \%$ ) vs $\mathrm{MO}^{\prime} 44 \%$ (95\% Cl 38\%-50\%)) and similar specificity (M2': 76\% (95\%Cl 74\%-78\%) vs Mo' 75\% (95\%Cl 73\%-77\%)) for validation dataset at NEWS2 $\geq 5$.

Conclusions Model M2' is reasonably accurate for predicting the on-admission risk of COVID-19. It may be clinically useful for an early warning system at the time of admission especially to triage large numbers of unplanned hospital admissions.

Keywords: vital signs, national early warning score, emergency admission, novel coronavirus SARS19 , computer-aided national early warning score 
medRxiv preprint doi: https://doi.org/10.1101/2020.11.30.20241257; this version posted December 2, 2020. The copyright holder for this preprint (which was not certified by peer review) is the author/funder, who has granted medRxiv a license to display the preprint in perpetuity.

All rights reserved. No reuse allowed without permission.

\section{Introduction}

The novel coronavirus SARS-19 produces the newly identified disease 'COVID-19' in patients with symptoms (Coronaviridae Study Group of the International Committee on Taxonomy of Viruses(1)) which was declared as a pandemic on 11-March-2020 that has challenged health care systems worldwide.

COVID-19 patients admitted to hospital can develop severe disease with life threatening respiratory and/or multi-organ failure $(2,3)$ with a high risk of mortality in part due to the lack of an effective treatment (bar supportive care) for the underlying disease. The appropriate early assessment and management of patients with COVID-19 is important in ensuring high-quality care including isolation, escalation to critical care or palliative care. Early assessment of the risk of COVID-19 is crucial to this process. Presently this involves clinical judgment based on the patients presenting history, signs and symptoms and viral nucleic acid testing can have a 24-hour turnaround time (4).

We posit that vital signs, which form the basis of Early Waning Scores (EWS) may be useful in supporting the clinical decision-making process before swab test results are available. EWS, which are widely used in hospitals worldwide, and in the National Health Service (NHS) hospitals in England, the patient's vital signs are monitored and summarised into a National Early Warning Score (NEWS)(5). NEWS offers a standardised approach to assessing acute illness and is derived from seven physiological variables or vital signs - respiration rate, oxygen saturations, any supplemental oxygen, temperature, systolic blood pressure, heart rate and level of consciousness (Alert (A), Voice (V), Pain $(\mathrm{P})$, Unresponsive $(\mathrm{U}))$ - which are routinely collected by nursing staff as an integral part of the process of care.

NEWS was launched by the Royal College of Physicians in 2012 (5) and has gained widespread interest from across the world, including Europe, India, the USA (and the US Navy)(6). In December 2017, an update to NEWS (NEWS2) was published (6) that extends the level of consciousness from AVPU to ACVPU, where $C$ represents new confusion or delirium and is allocated 3 points (the maximum for a single variable). NEWS2 also offers two scales for oxygen saturation (scale 1 and scale 2) which accommodates patients with hypercapnic respiratory failure who have clinically recommended oxygen saturation of $88-92 \%$.

Whilst hospitals continue to use NEWS2 during the COVID-19 pandemic, we determine the extent to which NEWS2 can be used predict the risk of COVID-19 by computer enhanced NEWS2 models. This approach is clinically useful because it places no additional data collection burden on staff whilst having the potential of providing an early indication of COVID-19 risk before findings of a swab test are reported - thus supporting early triage of COVID-19 and non-COVID-19 patients. 
medRxiv preprint doi: https://doi.org/10.1101/2020.11.30.20241257; this version posted December 2, 2020. The copyright holder for this preprint

(which was not certified by peer review) is the author/funder, who has granted medRxiv a license to display the preprint in perpetuity.

All rights reserved. No reuse allowed without permission.

\section{Methods}

\section{Setting \& data}

Our cohorts of emergency medical admissions are from two acute hospitals which are approximately 65 kilometres apart in the Yorkshire \& Humberside region of England - Scarborough hospital $(n \sim 300$ beds) and York Hospital (YH) ( $\mathrm{n} 700$ beds), managed by York Teaching Hospitals NHS Foundation Trust. We selected these hospitals because they had electronic NEWS2, which are collected as part of the patient's process of care and were agreeable to the study. Since NEWS2 extends NEWS, we use the same dataset to develop and validate NEWS and NEWS2 models, especially as NEWS is still in widespread use.

We considered all consecutive adult (age $\geq 18$ years) non-elective or emergency medical admissions discharged during 3 months (11 March 2020 to 13 June 2020), with electronic NEWS2. For each emergency admission, we obtained a pseudonymised patient identifier, patient's age (years), gender (male/female), discharge status (alive/dead), admission and discharge date and time, diagnoses codes based on the 10th revision of the International Statistical Classification of Diseases (ICD-10), NEWS2 (including its subcomponents respiratory rate, temperature, systolic pressure, pulse rate, oxygen saturation, oxygen supplementation, oxygen scales $1 \& 2$, and alertness including confusion). The diastolic blood pressure was recorded at the same time as systolic blood pressure. Historically, diastolic blood pressure has always been a routinely collected physiological variable on vital sign charts and is still collected where electronic observations are in place. NEWS2 produces integer values that range from 0 (indicating the lowest severity of illness) to 20 (the maximum NEWS2 value possible) (see Table S1 and S2 in supplementary material). The index NEWS2 was defined as the first electronically recorded NEWS2 within \pm 24 hours of the admission time. We excluded records where the index NEWS2 was not within \pm 24 hours or was missing/not recorded at all (see Table 1 ). The ICD10 code 'U071' was used to identify records with COVID-19. We searched primary and secondary ICD-10 codes for 'U071' for identifying COVID-19.

\section{Statistical Modelling}

We began with exploratory analyses including box plots that showed the relationship between covariates and risk of COVID-19 and line plots showed the relationship between age, vital signs, NEWS2 and risk of COVID-19. We developed three logistic regression models for each NEWS and NEWS2 separately predicting the risk of COVID-19. The NEWS models (M0, M1, M2) use the index or first recorded NEWS within \pm 24 hours of admission. Model M0 uses NEWS alone; Model M1 extends MO with age and sex and Model M2 extends M1 with all the subcomponents of NEWS plus diastolic 
medRxiv preprint doi: https://doi.org/10.1101/2020.11.30.20241257; this version posted December 2, 2020. The copyright holder for this preprint (which was not certified by peer review) is the author/funder, who has granted medRxiv a license to display the preprint in perpetuity.

All rights reserved. No reuse allowed without permission.

blood pressure. Equivalent models ( $\mathrm{MO}^{\prime}, \mathrm{M1}^{\prime}, \mathrm{M} 2^{\prime}$ ) using NEWS2 were also developed but they include oxygen flow rate as a continuous covariate and scale $1 /$ scale 2 as a binary covariate.

We used the qladder function (Stata (7)), which displays the quantiles of a transformed variable against the quantiles of a normal distribution according to the ladder powers $\left(x^{3}, x^{2}, x^{1}, x, \sqrt{x}, \log (x), x^{-1}, x^{-2}, x^{-3}\right)$ for each continuous covariate and chose the following transformations:- $\log _{\mathrm{e}}$ (respiratory rate), $\log _{\mathrm{e}}$ (pulse rate), $\log _{\mathrm{e}}$ (systolic blood pressure), and $\log _{\mathrm{e}}$ (diastolic blood pressure).

We developed all models using York Hospital (YH) data (as development dataset) and externally validated their performance on Scarborough Hospital (SH) data (as validation dataset). The hospitals are part of the same NHS Trust but are geographically separated by about 65 kilometres ( 40 miles).

We report discrimination and calibration statistics as performance measures for these models (8).

Discrimination relates to how well a model can separate, (or discriminate) between admissions with and without COVID-19 and is given by the area under the Receiver Operating Characteristics (ROC) curve (AUC) or c-statistic. The ROC curve is a plot of the sensitivity, (true positive rate), versus 1specificity, (false positive rate), for consecutive predicted risks. A c-statistic of 0.5 is no better than tossing a coin, whilst a perfect model has a c-statistic of 1 . In general, values less than 0.7 are considered to show poor discrimination, values of 0.7 to 0.8 can be described as reasonable, and values above 0.8 suggest good discrimination (9). The $95 \%$ confidence interval for the c-statistic was derived using DeLong's method as implemented in the pROC library (10) in R (11).

Calibration is the relationship between the observed and predicted risk of COVID-19 (24) and can be readily seen on a scatter plot ( $y$-axis observed risk, $x$-axis predicted risk). Perfect predictions should be on the $45^{\circ}$ line. We internally validated and assessed the calibration for all the models using the bootstrapping approach $(12,13)$. The overall statistical performance was assessed using the scaled Brier score which incorporates both discrimination and calibration (8). The Brier score is the squared difference between actual outcomes and predicted risk of COVID-19, scaled by the maximum Brier score such that the scaled Brier score ranges from 0-100\%. Higher values indicate superior models.

The cut-off of NEWS2 is 5 or more. This is the recommended threshold for detecting deteriorating patients and sepsis $(14,15)$. Therefore, we assessed the sensitivity, specificity, positive and negative predictive values and likelihood ratios for these models at NEWS2 threshold of 5+ (16). We further compared the Net Benefit for all these NEWS and NEWS2 models, which may inform the utility of the models in routine clinical practice (17). The net benefit is calculated at a particular threshold probability $p_{t}$ with total sample size $N$ as follows: 
medRxiv preprint doi: https://doi.org/10.1101/2020.11.30.20241257; this version posted December 2, 2020. The copyright holder for this preprint

(which was not certified by peer review) is the author/funder, who has granted medRxiv a license to display the preprint in perpetuity.

All rights reserved. No reuse allowed without permission.

$$
\text { Net benefit }=\frac{\text { True positives }}{N}-\frac{\text { False positivies }}{N} \times \frac{p_{t}}{1-p_{t}}
$$

The highest net benefit has the highest clinical value.

We calculated the minimum sample size using the R package pmsampsize (18). We found 930 (93 events) is minimum required sample size with number of predictors $=21, \mathrm{R} 2=0.182$, prevalence $=0.10$, shrinkage $>0.9$, margin absolute prediction error (MAPE) $=0.05$ (19). We followed the TRIPOD guidelines for reporting of model development and validation (20). We used Stata (7) for data cleaning and $R(11)$ for statistical analysis.

\section{Results}

\section{Cohort Characteristics}

The number of non-elective discharges was 6444 over 3 months. We excluded $36(0.6 \%)$ of admissions because the index NEWS was not recorded within \pm 24 hours of the admission date/time or there was missing or no recorded at all (see Table S3).

The characteristics of the admissions included in our study are shown in Table 1. Emergency admissions in the validation dataset were older than those in development dataset 69.6 years vs 67.4 years), less likely to be male ( $49.5 \%$ vs $51.2 \%$ ), had higher index NEWS ( 2.8 vs 2.5 ) and NEWS2 (3.2 vs 2.8 ), higher prevalence of COVID-19 ( $11.0 \%$ vs $8.7 \%$ ) but similar in-hospital mortality $(8.4 \%$ vs $8.2 \%)$. See accompanying scatter and boxplots in Figure S1 to S4 - supplemental digital content. 
medRxiv preprint doi: https://doi.org/10.1101/2020.11.30.20241257; this version posted December 2, 2020. The copyright holder for this preprint (which was not certified by peer review) is the author/funder, who has granted medRxiv a license to display the preprint in perpetuity.

\begin{tabular}{|c|c|c|c|c|}
\hline Characteristic & $\begin{array}{l}\text { Development } \\
\text { dataset (YH) }\end{array}$ & $\begin{array}{l}\text { Validation } \\
\text { dataset (SH) }\end{array}$ & $\begin{array}{l}\text { Degree of } \\
\text { freedom } \\
\text { (df) }\end{array}$ & p-value \\
\hline $\mathrm{N}$ & 3924 & 2520 & & - \\
\hline Male (\%) & $2010(51.2)$ & $1247(49.5)$ & 1 & 0.181 \\
\hline Mean Age [years] (SD) & $67.4(18.7)$ & $69.6(18.9)$ & 5320 & $<0.001$ \\
\hline Median Length of Stay (days) (IQR) & $3.0(5.8)$ & $3.7(6.1)$ & - & $<0.001$ \\
\hline COVID-19 (\%) & $343(8.7)$ & $277(11.0)$ & 1 & 0.003 \\
\hline \multicolumn{5}{|l|}{ Mortality } \\
\hline Mortality with-in 24 hours (\%) & $30(0.8)$ & $32(1.3)$ & 1 & 0.058 \\
\hline Mortality with-in 48 hours (\%) & $61(1.6)$ & $48(1.9)$ & 1 & 0.335 \\
\hline Mortality with-in 72 hours (\%) & $96(2.4)$ & $68(2.7)$ & 1 & 0.585 \\
\hline In-hospital Mortality & $323(8.2)$ & $212(8.4)$ & 1 & 0.833 \\
\hline Mean NEWS (SD) & $2.5(2.3)$ & $2.8(2.4)$ & 5201 & $<0.001$ \\
\hline Mean NEWS2 (SD) & $2.8(2.8)$ & $3.2(2.8)$ & 5446 & $<0.001$ \\
\hline \multicolumn{5}{|l|}{ Vital Signs } \\
\hline $\begin{array}{c}\text { Mean Respiratory rate [breaths per } \\
\text { minute] (SD) }\end{array}$ & $19.8(5.1)$ & $20.7(5.6)$ & 5027 & $<0.001$ \\
\hline Mean Temperature $\left[{ }^{\circ} \mathrm{C}\right](\mathrm{SD})$ & $36.4(0.9)$ & $36.3(1)$ & 4817 & 0.001 \\
\hline Mean Systolic pressure [mmHg] (SD) & $141.8(29.2)$ & $142(28.5)$ & 5455 & 0.839 \\
\hline Mean Diastolic pressure [mmHg] (SD) & $79.2(16.5)$ & $79(17.3)$ & 5193 & 0.545 \\
\hline $\begin{array}{l}\text { Mean Pulse rate [beats per minute] } \\
\text { (SD) }\end{array}$ & $89.1(22.3)$ & $88.5(22.1)$ & 5406 & 0.336 \\
\hline Mean Oxygen saturation (SD) & $96.3(3.1)$ & $96.1(3.2)$ & 5182 & 0.059 \\
\hline Oxygen supplementation (\%) & $512(13)$ & $362(14.4)$ & 1 & 0.142 \\
\hline Mean oxygen flow rate (units) (SD) & $7.1(5.7)$ & $6.1(5.3)$ & 811 & 0.007 \\
\hline Oxygen scale 2 (yes) (\%) & $240(6.1)$ & $163(6.5)$ & 1 & 0.605 \\
\hline \multicolumn{5}{|l|}{ Alertness } \\
\hline Alert (\%) & $3510(89.4)$ & $2243(89)$ & 5 & 0.010 \\
\hline Baseline confusion (\%) & $27(0.7)$ & $23(0.9)$ & & \\
\hline New confusion $(\%)$ & $61(1.6)$ & $40(1.6)$ & & \\
\hline Pain (\%) & $32(0.8)$ & $17(0.7)$ & & \\
\hline Voice (\%) & $151(3.8)$ & $134(5.3)$ & & \\
\hline Unconscious (\%) & $143(3.6)$ & $63(2.5)$ & & \\
\hline
\end{tabular}

Table 1 Characteristics of emergency medical admissions in development and validation datasets. 

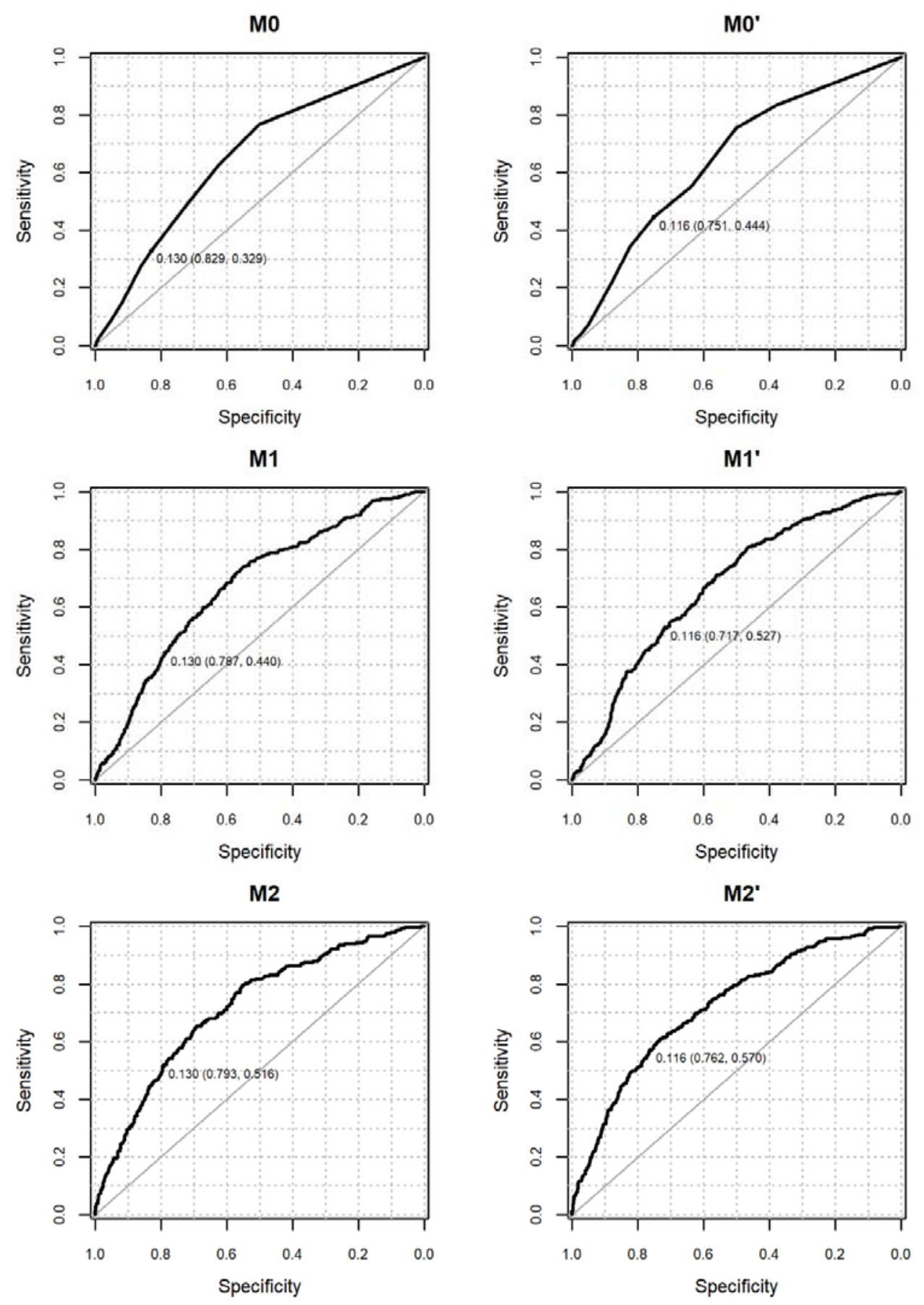

Figure 1 Receiver Operating Characteristic curve for NEWS (left column) and NEWS2 (right column) in predicting the risk of COVID-19 on admission for model M0/MO', M1/M1', and M2/M2' in the validation dataset

Note: predicted probability at NEWS (or NEWS2) threshold $\geq 5$ (sensitivity, specificity) is shown for all models. 
medRxiv preprint doi: https://doi.org/10.1101/2020.11.30.20241257; this version posted December 2, 2020. The copyright holder for this preprint (which was not certified by peer review) is the author/funder, who has granted medRxiv a license to display the preprint in perpetuity.

All rights reserved. No reuse allowed without permission.

We assessed the performance of index NEWS/NEWS2 models to predict the risk of COVID-19 in emergency medical admissions (see Table 2 and Figure 1). The c-statistics for predicting COVID-19 for Model $\mathrm{M2}^{\prime}$ is better than NEWS2 alone $\mathrm{MO}^{\prime}$ model in development $\left(\mathrm{MO}^{\prime}=0.71 ; \mathrm{M1}^{\prime}=0.72, \mathrm{M} 2^{\prime}\right.$ : $0.78)$ and the validation dataset $\left(\mathrm{MO}^{\prime}=0.65 ; \mathrm{M}^{\prime}=0.67, \mathrm{M}^{\prime}: 0.72\right)$. Moreover, the $c$-statistics for predicting COVID-19 for NEWS2 models was similar to NEWS models in both, development and validation datasets.

\begin{tabular}{|c|c|c|c|c|c|c|}
\hline Model & $\begin{array}{l}\text { Mean Risk } \\
\text { Non-COVID }\end{array}$ & $\begin{array}{c}\text { Mean Risk } \\
\text { COVID }\end{array}$ & ARD & $\begin{array}{l}\text { Scaled Brier } \\
\text { Score }\end{array}$ & $\operatorname{AUC}(95 \% \mathrm{Cls})$ & Calibration Slope \\
\hline MO & 0.11 & 0.14 & 0.03 & 0.01 & $\begin{array}{c}0.65 \\
(0.62 \text { to } 0.69)\end{array}$ & $\begin{array}{c}0.72 \\
(0.53 \text { to } 0.91)\end{array}$ \\
\hline M1 & 0.11 & 0.14 & 0.04 & 0.02 & $\begin{array}{c}0.67 \\
(0.64 \text { to } 0.7)\end{array}$ & $\begin{array}{c}0.81 \\
(0.63 \text { to } 0.99)\end{array}$ \\
\hline M2 & 0.10 & 0.18 & 0.08 & 0.05 & $\begin{array}{c}0.72 \\
(0.69 \text { to } 0.75) \\
\end{array}$ & $\begin{array}{c}0.78 \\
(0.65 \text { to } 0.91) \\
\end{array}$ \\
\hline MO' & 0.11 & 0.14 & 0.03 & 0.00 & $\begin{array}{c}0.65 \\
\text { (0.61 to } 0.68)\end{array}$ & $\begin{array}{c}0.69 \\
(0.51 \text { to } 0.87)\end{array}$ \\
\hline M1 & 0.11 & 0.14 & 0.04 & 0.01 & $\begin{array}{c}0.67 \\
(0.64 \text { to } 0.7)\end{array}$ & $\begin{array}{c}0.78 \\
(0.60 \text { to } 0.96)\end{array}$ \\
\hline M2 & 0.10 & 0.19 & 0.09 & 0.06 & $\begin{array}{c}0.72 \\
(0.69 \text { to } 0.75)\end{array}$ & $\begin{array}{c}0.76 \\
(0.64 \text { to } 0.89) \\
\end{array}$ \\
\hline
\end{tabular}

Table 2: Performance of NEWS and NEWS2 models for predicting the risk of COVID on admission for validation dataset

ARD: absolute risk difference; AUC: Area under the curve; Cls: confidence intervals

Table 3 includes the sensitivity, specificity, positive and negative predictive values for NEWS and NEWS2 models for predicting COVID-19. NEWS2 models had higher sensitivity but lower specificity compared to NEWS models because the predicted probability at NEWS $2 \geq 5(0.116)$ is smaller than at NEWS $\geq 5(0.13)$

Model M2' had better calibration than Model Mo' (M2': 0.78 (95\% Cl 0.65 vs 0.91$)$ vs $0.69(95 \% \mathrm{Cl}$ 0.51 to 0.87$)$ ) (see Table $2 \&$ S4 and Figure 1 \& S7) with improved sensitivity (M2': 57\% (95\%Cl 5163) vs $\left.\mathrm{MO}^{\prime} 44 \%(95 \% \mathrm{Cl} 38-50)\right)$ and similar specificity ( $\mathrm{M2}^{\prime}: 76 \%(95 \% \mathrm{Cl} 74-78)$ vs $\mathrm{MO}{ }^{\prime} 75 \%(95 \% \mathrm{Cl}$ 73-77)) for validation dataset at NEWS2 $\geq 5$ (see Table $3 \&$ S5). Internal validation of these models is shown in Figure S6. Figure 2 shows model calibration improved across the models and that models $M 2^{\prime}$ and $M 2$ are well-calibrated. 
medRxiv preprint doi: https://doi.org/10.1101/2020.11.30.20241257; this version posted December 2, 2020. The copyright holder for this preprint (which was not certified by peer review) is the author/funder, who has granted medRxiv a license to display the preprint in perpetuity.

All rights reserved. No reuse allowed without permission.

Model M2'/M2 had highest clinical utility than Model $\mathrm{MO}^{\prime} / \mathrm{MO}$ for validation datasets (see Figure 3) and development dataset (see Figure S8). Nevertheless, NEWS/NEWS2 $\geq 5$ is the worst performing choice compared to the cNEWS models.

(M0)

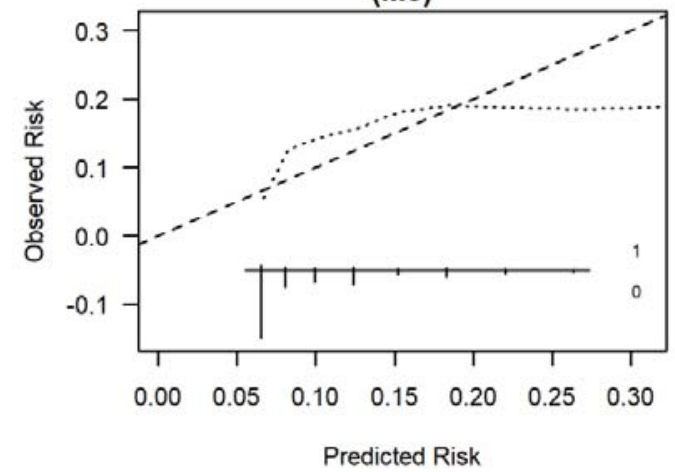

(M1)

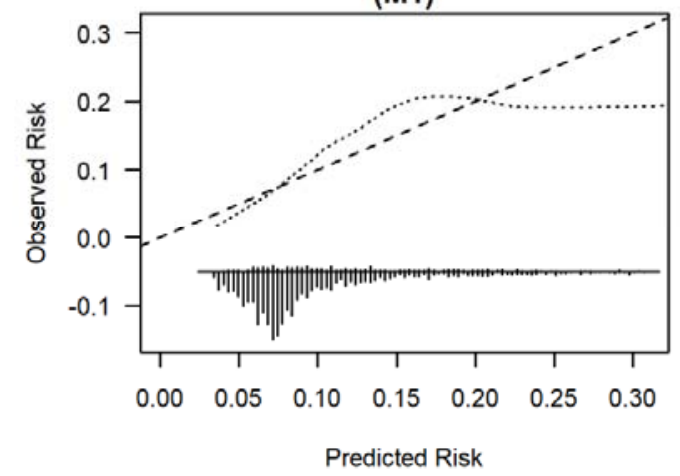

(M2)

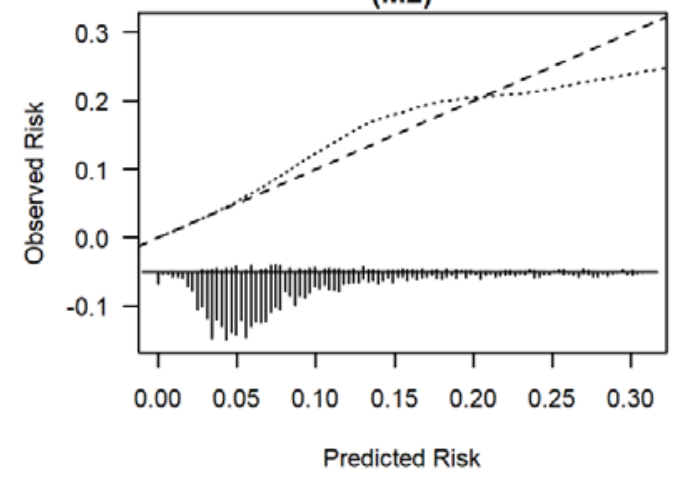

(MO')

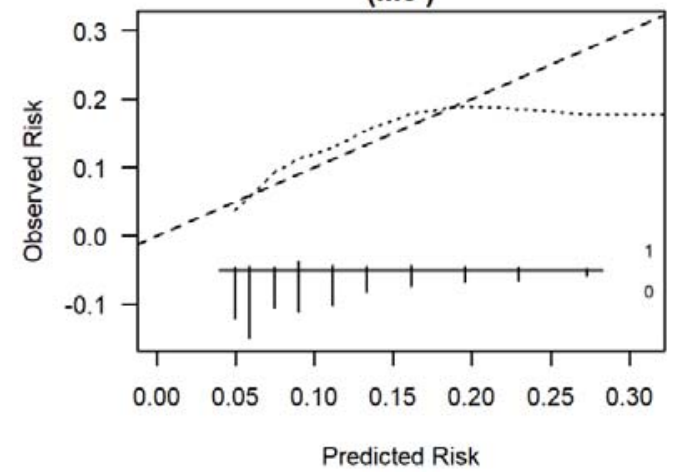

(M1')

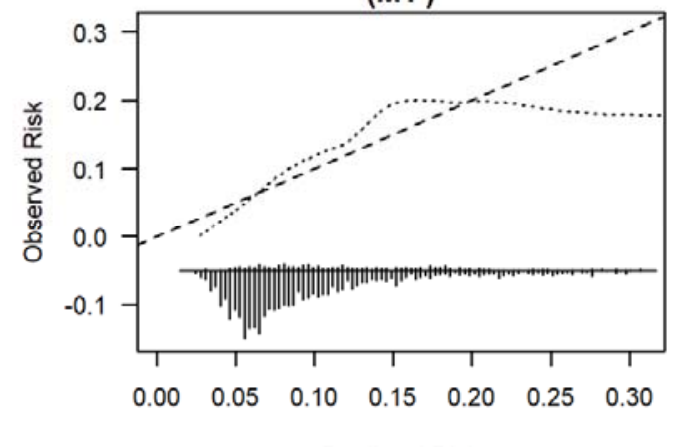

Predicted Risk

(M2')

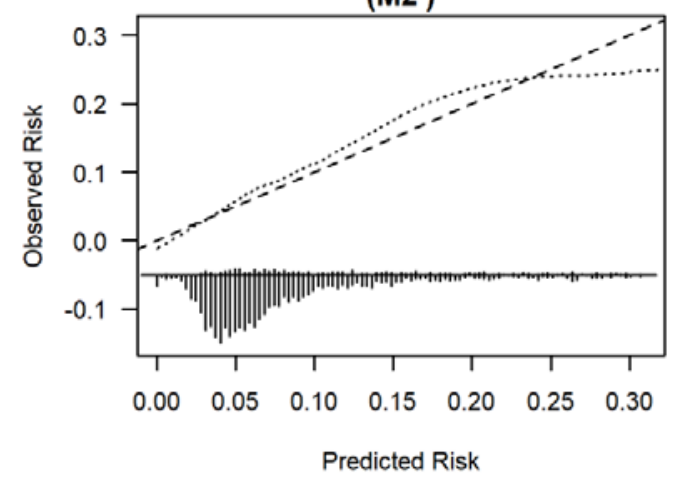

Figure 2 External validation of all NEWS (M0, M1, M2) and NEWS2 (MO', M1', M2') models, respectively for predicting the risk of COVID-19

NB: We limit the risk of COVID-19 to 0.30 for visualisation purpose because beyond this point, we have few patients. 
medRxiv preprint doi: https://doi.org/10.1101/2020.11.30.20241257; this version posted December 2, 2020. The copyright holder for this preprint (which was not certified by peer review) is the author/funder, who has granted medRxiv a license to display the preprint in perpetuity.

All rights reserved. No reuse allowed without permission.

\begin{tabular}{|c|c|c|c|c|c|c|c|}
\hline Model & $\begin{array}{c}\text { Number of } \\
\text { positive cases } \\
\text { identified by } \\
\text { model }\end{array}$ & Sensitivity\% & Specificity\% & PPV & NPV & LR+ & LR- \\
\hline MO & 474 & $\begin{array}{c}32.9 \\
(27.4 \text { to } 38.7)\end{array}$ & $\begin{array}{c}82.9 \\
\text { (81.3 to } 84.5)\end{array}$ & $\begin{array}{c}19.2 \\
(15.7 \text { to } 23)\end{array}$ & $\begin{array}{c}90.9 \\
(89.6 \text { to } 92.1)\end{array}$ & $\begin{array}{c}1.9 \\
(1.6 \text { to } 2.3)\end{array}$ & $\begin{array}{c}0.8 \\
(0.7 \text { to } 0.9)\end{array}$ \\
\hline M1 & 600 & $\begin{array}{c}44 \\
\text { (38.1 to } 50.1 \text { ) }\end{array}$ & $\begin{array}{c}78.7 \\
\text { (76.9 to } 80.4 \text { ) }\end{array}$ & $\begin{array}{c}20.3 \\
(17.2 \text { to } 23.8)\end{array}$ & $\begin{array}{c}91.9 \\
\text { (90.6 to } 93.1)\end{array}$ & $\begin{array}{c}2.1 \\
(1.8 \text { to } 2.4)\end{array}$ & $\begin{array}{c}0.7 \\
(0.6 \text { to } 0.8)\end{array}$ \\
\hline M2 & 607 & $\begin{array}{c}51.6 \\
(45.6 \text { to } 57.6)\end{array}$ & $\begin{array}{c}79.3 \\
\text { (77.6 to } 81)\end{array}$ & $\begin{array}{c}23.6 \\
(20.2 \text { to } 27.1) \\
\end{array}$ & $\begin{array}{c}93 \\
\text { (91.8 to } 94.1 \text { ) }\end{array}$ & $\begin{array}{c}2.5 \\
(2.2 \text { to } 2.9)\end{array}$ & $\begin{array}{c}0.6 \\
(0.5 \text { to } 0.7)\end{array}$ \\
\hline Mo' & 681 & $\begin{array}{c}44.4 \\
(38.5 \text { to } 50.5)\end{array}$ & $\begin{array}{c}75.1 \\
\text { (73.3 to } 76.9)\end{array}$ & $\begin{array}{c}18.1 \\
(15.2 \text { to } 21.2)\end{array}$ & $\begin{array}{c}91.6 \\
(90.3 \text { to } 92.9)\end{array}$ & $\begin{array}{c}1.8 \\
(1.5 \text { to } 2.1) \\
\end{array}$ & $\begin{array}{c}0.7 \\
(0.7 \text { to } 0.8)\end{array}$ \\
\hline M1 & 781 & $\begin{array}{c}52.7 \\
(46.6 \text { to } 58.7) \\
\end{array}$ & $\begin{array}{c}71.7 \\
\text { (69.8 to } 73.5) \\
\end{array}$ & $\begin{array}{c}18.7 \\
(16 \text { to } 21.6) \\
\end{array}$ & $\begin{array}{c}92.5 \\
\text { (91.1 to 93.7) } \\
\end{array}$ & $\begin{array}{c}1.9 \\
\text { (1.6 to } 2.1 \text { ) }\end{array}$ & $\begin{array}{c}0.7 \\
(0.6 \text { to } 0.7)\end{array}$ \\
\hline M2 & 692 & $\begin{array}{c}57 \\
\text { (51 to } 62.9) \\
\end{array}$ & $\begin{array}{c}76.2 \\
\text { (74.4 to } 77.9) \\
\end{array}$ & $\begin{array}{c}22.8 \\
\text { (19.8 to } 26.1) \\
\end{array}$ & $\begin{array}{c}93.5 \\
(92.3 \text { to } 94.6) \\
\end{array}$ & $\begin{array}{c}2.4 \\
\text { (2.1 to } 2.7)\end{array}$ & $\begin{array}{c}0.6 \\
(0.5 \text { to } 0.6)\end{array}$ \\
\hline
\end{tabular}

Table 3 Sensitivity analysis of three models for each NEWS and NEWS2 for predicting the risk of COVID at threshold $\geq 5$ of NEWS (predicted probability of model $M 0=0.130$ ) and NEWS2 (predicted probability of model $\mathrm{MO}^{\prime}=\mathbf{0 . 1 1 6}$ ) for validation dataset.

PPV=Positive Predictive Value; NPV= Negative Predictive Value; LR+=Positive Likelihood Ratio; LR-=Negative Likelihood Ratio

NEWS

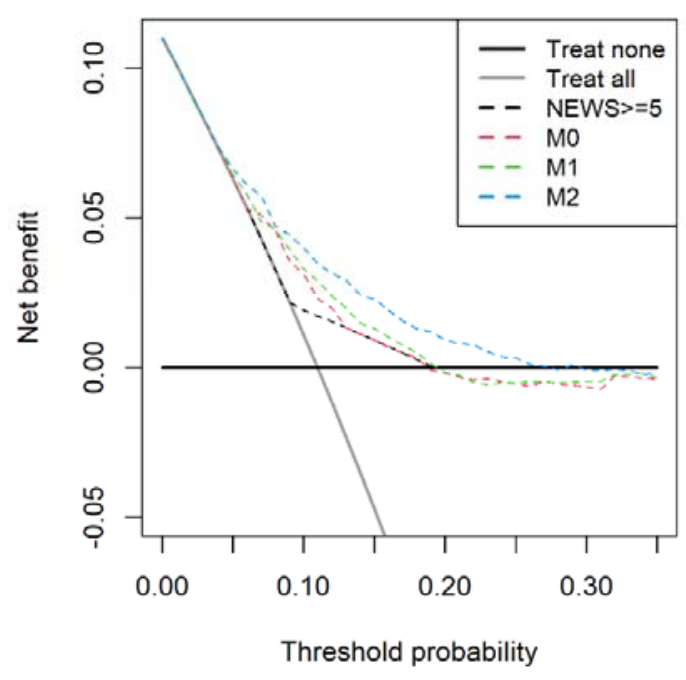

NEWS2

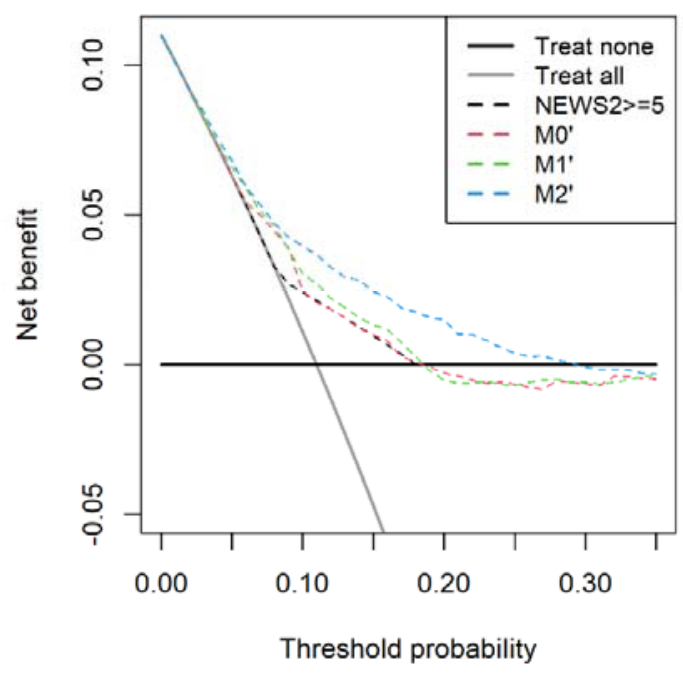

Figure 3 Net Benefit for model MO/MO', M1/M1', and M2/M2' in predicting the risk of COVID-19 on admission in the validation dataset 
medRxiv preprint doi: https://doi.org/10.1101/2020.11.30.20241257; this version posted December 2, 2020. The copyright holder for this preprint (which was not certified by peer review) is the author/funder, who has granted medRxiv a license to display the preprint in perpetuity.

All rights reserved. No reuse allowed without permission.

\section{Discussion}

In this study, we developed and validated three computer-aided versions of NEWS/NEWS2 based models which incorporated progressively more information. Model M0 uses NEWS alone; Model M1 extends M0 with age and sex; Model M2 extends M1 with all the subcomponents of NEWS plus diastolic blood pressure. Equivalent models ( $\mathrm{MO}^{\prime}, \mathrm{M1}^{\prime}, \mathrm{M2}^{\prime}$ ) were developed using NEWS2 (see appendix for equations and escalation policy Figure S5).

NEWS2 models were more sensitive but less specific than NEWS models. Models M2 and M2' were the best in class, with the highest c-statistics ( 0.77 and 0.72 respectively). The high negative predictive value suggests models $\mathrm{M} 2$ and M2' may be particularly useful in ruling out COVID-19 early in the patients unplanned admission which is clinically useful because testing for COVID-19 using viral nucleic acid testing is time consuming.

A recent systematic review identified five models to detect COVID-19 infection in symptomatic individuals with c-statistics that ranged from 0.87 to 1 (21). However, despite these high c-statistics, the review authors cautioned against the use of these models in clinical practice because of the high risk of bias and poor reporting of studies which are likely to have led to optimistic results (21).

The main advantages of our computer-aided NEWS2 models are that they are designed to incorporate data which are already available in the patient's electronic health record and so place no additional data collection or computational burden on clinicians and they are readily automated. Nonetheless, we emphasize that our computer-aided risk scores are not designed to replace clinical judgement. They are intended and designed to support, not subvert, the clinical decision-making process and can be always overridden by clinical concern $(5,22)$. The working hypothesis for our computer-aided NEWS scores is that they may enhance situational awareness of COVID-19 by processing information already available without impeding the workflow of clinical staff, especially as our approach offers a faster and less expensive assessment of COVID-19 risk than current laboratory tests which may be more practical to use for large numbers of people.

There are limitations in relation to our study. We identified COVID-19 based on ICD-10 code 'U071' which was determined by clinical judgment and/or swab test results and so our findings are constrained by the accuracy of these methods $(23,24)$. We used the index NEWS or NEWS2 data in our models, which reflects the "on-admission" risk of COVID-19 of the patient. Nonetheless, vital signs are repeatedly updated for each patient according to hospital protocols. Although we developed models using one hospital data and validated into other hospital data, the extent to which changes in vital signs over time reflect changes in COVID-19 risk that need to be incorporated in our models needs further study. While most of the studies reported insufficient sample size (25), 
our study was sufficiently large for developing and validating relatively simple NEWS/NEWS2 based prediction models(19). Our two hospitals are part of the same NHS Trust and this may undermine the generalisability of our findings, which merit further external validation.

Furthermore, a crucial next phase of this work is to field test our models by carefully engineering then into routine clinical practice $(26,27)$ to see if they do support the earlier detection and care of COVID-19 in emergency medical patients without unintended adverse consequences.

\section{Conclusion}

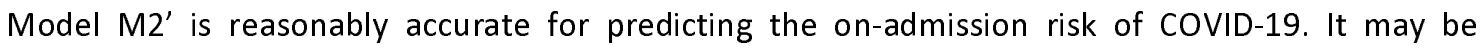
clinically useful for an early warning system at the time of admission especially to triage large numbers of unplanned hospital admissions.

\section{Competing Interests}

The authors declare no conflicts of interest. All authors have completed the(available on request from the corresponding author) and declare: no support from any organisation for the submitted work [other than the funders described below]; no financial relationships with any organisations that might have an interest in the submitted work in the previous three years, no other relationships or activities that could appear to have influenced the submitted work.

\section{Funding}

This research was supported by the Health Foundation. The Health Foundation is an independent charity working to improve the quality of healthcare in the UK. This research was supported by the National Institute for Health Research (NIHR) Yorkshire and Humber Patient Safety Translational Research Centre (NIHR Yorkshire and Humber PSTRC). The views expressed in this article are those of the author(s) and not necessarily those of the NHS, the Health Foundation, the NIHR, or the Department of Health.

\section{Role of the funding source}

The funders of the study had no role in study design, data collection, data analysis, data interpretation, or writing of the report.

\section{Author contributions}

DR and MAM had the original idea for the work. KB, RH provided the data extracts. MF undertook the statistical analyses with support from MAM. MF, MAM, and DR wrote the first draft of the paper. DR, SI and KS provided clinical perspectives. EW provided critical guidance and support. All others 
medRxiv preprint doi: https://doi.org/10.1101/2020.11.30.20241257; this version posted December 2, 2020. The copyright holder for this preprint (which was not certified by peer review) is the author/funder, who has granted medRxiv a license to display the preprint in perpetuity.

All rights reserved. No reuse allowed without permission.

contributed to the final paper and have approved the final version. DR \& MF will act as study guarantors.

\section{Transparency declaration}

The lead author (the manuscript's guarantor) affirms that the manuscript is an honest, accurate, and transparent account of the study being reported; that no important aspects of the study have been omitted.

\section{Ethical Approval}

This study was deemed to be exempt from ethical approval because it was classified as an evaluation. Furthermore, this study used already de-identified data from an ongoing study involving NEWS which received ethical approval from Health Research Authority (HRA) and Health and Care Research Wales (HCRW) (reference number 19/HRA/0548).

Patient involvement: none

Data sharing: our data sharing agreement is with York hospital and does not permit us to share the data used in this paper.

\section{References}

1. Gorbalenya AE, Baker SC, Baric RS, et al.: The species Severe acute respiratory syndromerelated coronavirus: classifying 2019-nCoV and naming it SARS-CoV-2 [Internet]. Nat Microbiol 2020; 5:536-544[cited 2020 Jun 24] Available from: https://www.nature.com/articles/s41564-020-0695-z

2. Onder G, Rezza G, Brusaferro S: Case-Fatality Rate and Characteristics of Patients Dying in Relation to COVID-19 in Italy [Internet]. JAMA - J Am Med Assoc 2020; 323:1775-1776[cited 2020 Jun 24] Available from: https://jamanetwork.com/journals/jama/fullarticle/2763667

3. Vincent JL, Taccone FS: Understanding pathways to death in patients with COVID-19 [Internet]. Lancet Respir Med 2020; 8:430-432[cited 2020 Jun 24] Available from: http://www.thelancet.com/article/S221326002030165X/fulltext

4. Weekly statistics for NHS Test and Trace (England) and coronavirus testing (UK): 24 September to 30 September - GOV.UK [Internet]. [cited 2020 Oct 14] Available from: https://www.gov.uk/government/publications/nhs-test-and-trace-england-and-coronavirustesting-uk-statistics-24-september-to-30-september-2020/weekly-statistics-for-nhs-test-andtrace-england-and-coronavirus-testing-uk-24-september-to-30-september

5. Royal College of Physicians: National Early Warning Score (NEWS): Standardising the assessment of acuteillness severity in the NHS - Report of a working party. 2012;

6. NHS: Royal College of Physicians: NHS England approves use of National Early Warning Score (NEWS) 2 to improve detection of acutely ill patients. [Internet]. 2017. Available from: https://www.rcplondon.ac.uk/news/nhs-england-approves-use-national-early-warning-scorenews-2-improve-detection-acutely-ill

7. StatCorp: Stata: Release 14. Statistical Software. College Station, TX: StataCorp LP. 2016; 
8. Steyerberg EW: Clinical Prediction Models. A practical approach to development, validation and updating. Springer; 2008.

9. Hanley JA, McNeil BJ: The meaning and use of the area under a receiver operating characteristic (ROC) curve. Radiology 1982; 143:29-36

10. Robin X, Turck N, Hainard A, et al.: pROC: an open-source package for R and S+ to analyze and compare ROC curves. BMC Bioinformatics 2011; $12: 77$

11. R Development Core Team: $R$ : A language and environment for statistical computing. $R$ Foundation for Statistical Computing http://www.r-project.org/. 2015;

12. Steyerberg EW, Harrell FE, Borsboom GJJ., et al.: Internal validation of predictive models: Efficiency of some procedures for logistic regression analysis. J Clin Epidemiol 2001; 54:774781

13. Harrell FE: rms: Regression Modeling Strategies http://cran.r-project.org/package=rms. 2015;

14. National Institute for Health and Care Excellence. Sepsis Quality Standard [QS161]. Published September 2017 [Internet]. Available from: https://www.nice.org.uk/guidance/qs161/resources/sepsis-pdf-75545595402181

15. NHS England. Sepsis Guidance implementation advice for adults: NHS England, Sept 17 [Internet]. Available from: https://www.england.nhs.uk/wpcontent/uploads/2017/09/sepsis-guidance-implementation-advice-for-adults.pdf

16. Sing $\mathrm{T}$, Sander $\mathrm{O}$, Beerenwinkel $\mathrm{N}$, et al.: ROCR: visualizing classifier performance in $\mathrm{R}$. Bioinformatics 2005; 21:3940-3941

17. Vickers AJ, Elkin EB: Decision curve analysis: a novel method for evaluating prediction models. [Internet]. Med Decis Making 2006; 26:565-74[cited 2016 Jun 3] Available from: http://mdm.sagepub.com/content/26/6/565.short

18. CRAN - Package pmsampsize [Internet]. [cited 2020 Aug 3] Available from: https://cran.rproject.org/web/packages/pmsampsize/index.html

19. Riley RD, Ensor J, Snell KIE, et al.: Calculating the sample size required for developing a clinical prediction model. BMJ 2020; 368

20. Moons KGM, Altman DG, Reitsma JB, et al.: Transparent Reporting of a multivariable prediction model for Individual Prognosis Or Diagnosis (TRIPOD): Explanation and Elaboration [Internet]. Ann Intern Med 2015; 162:W1[cited 2018 Jun 26] Available from: http://annals.org/article. aspx?doi=10.7326/M14-0698

21. Wynants L, Van Calster B, Collins GS, et al.: Prediction models for diagnosis and prognosis of covid-19: Systematic review and critical appraisal [Internet]. BMJ 2020; 369:18 [cited 2020 Aug 3] Available from: https://www.bmj.com/content/369/bmj.m1328

22. Balamuth F, Alpern ER, Abbadessa MK, et al.: Improving Recognition of Pediatric Severe Sepsis in the Emergency Department: Contributions of a Vital Sign-Based Electronic Alert and Bedside Clinician Identification. Ann Emerg Med 2017; 70:759-768.e2

23. Corfield AR, Lees F, Zealley I, et al.: Utility of a single early warning score in patients with sepsis in the emergency department. 2012;

24. Churpek MM, Snyder A, Han X, et al.: Quick Sepsis-related Organ Failure Assessment, Systemic Inflammatory Response Syndrome, and Early Warning Scores for Detecting Clinical Deterioration in Infected Patients outside the Intensive Care Unit. Am J Respir Crit Care Med 2017; 195:906-911

25. Sperrin M, Grant SW, Peek N: Prediction models for diagnosis and prognosis in Covid-19. BMJ 2020; 369 
medRxiv preprint doi: https://doi.org/10.1101/2020.11.30.20241257; this version posted December 2, 2020. The copyright holder for this preprint (which was not certified by peer review) is the author/funder, who has granted medRxiv a license to display the preprint in perpetuity.

All rights reserved. No reuse allowed without permission.

26. Escobar GJ, Dellinger RP: Early detection, prevention, and mitigation of critical illness outside intensive care settings. J Hosp Med 2016; 11:S5-S10

27. Escobar GJ, Turk BJ, Ragins A, et al.: Piloting electronic medical record-based early detection of inpatient deterioration in community hospitals. J Hosp Med 2016; 11:S18-S24 